\title{
Surveillance of laboratory exposures to human pathogens and toxins, Canada 2019
}

\author{
Amanda Lien ${ }^{1}$, Christine Abalos ${ }^{1}$, Nicole Atchessi ${ }^{1}$, Rojiemiahd Edjoc $^{1 \star}$, Marianne Heisz ${ }^{1}$
}

\begin{abstract}
Background: The Human Pathogens Act and the Human Pathogens and Toxins Regulations mandates laboratory incident reporting to the Public Health Agency of Canada's Laboratory Incident Notification Canada (LINC) surveillance system. The objective of this report is to describe laboratory incidents involving exposures that occurred in Canada during 2019 and individuals affected in these incidents.
\end{abstract}

Methods: Laboratory incidents occurring in licensed Canadian laboratories in 2019 were analyzed. Exposure incident rate was calculated and descriptive statistics were performed. Exposure incidents were analyzed by sector, root cause, activity, occurrence type, and pathogen/toxin. Affected persons were analyzed by education, route of exposure, sector, role and laboratory experience.

Results: Sixty exposure incidents involving 86 individuals were reported to LINC in 2019. The annual exposure rate was six incidents per 100 active licenses. Most exposure incidents involved microbiology $(n=39 ; 65 \%)$ activities and/or were reported by the academic $(n=22 ; 37 \%)$ sector. The public health sector had the highest proportion of exposure incidents while the private sector had the lowest. Procedural $(n=18,23 \%)$ was the most cited occurrence type. Over a third of exposed individuals had $0-5$ years of laboratory experience $(n=32 ; 37 \%)$ and were hospital technicians or technologists $(n=31 ; 36 \%)$. Inhalation was the most common route of exposure $(n=53,62 \%)$. Human interaction $(n=35 ; 24 \%)$ was the most cited root cause.

Conclusion: Laboratory incidents were lower in 2019 than in 2018. The most common occurrence type was procedural while issues with human interaction was the most cited root cause. Most exposed individuals were hospital technicians or technologists.
This work is licensed under a Creative Commons Attribution 4.0 International License.

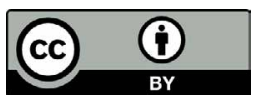

Affiliation

${ }^{1}$ Centre for Biosecurity, Public Health Agency of Canada, Ottawa, ON

\section{${ }^{\star}$ Correspondence:}

rojiemiahd.edjoc@canada.ca

Suggested citation: Lien A, Abalos C, Atchessi N, Edjoc R, Heisz M. Surveillance of laboratory exposures to human pathogens and toxins, Canada 2019. Can Commun Dis Rep 2020;46(9):292-8.

https://doi.org/10.14745/ccdr.v46i09a07

Keywords: laboratory exposures, laboratory incidents, laboratory-acquired infections, human pathogens and toxins, surveillance, Laboratory Incident Notification Canada, Centre for Biosecurity

\section{Introduction}

When working in a laboratory setting with human pathogens and toxins (HPTs), there is an inherent risk of deliberate or accidental exposure. Timely reporting of exposure incidents is essential to mitigate the risk of potential outbreaks and permit a rapid action response. In recent years, this risk to human biosafety and biosecurity to laboratory-acquired infections (LAls) through exposure has led Canada to establish one of the first comprehensive national surveillance systems for mandatory reporting of laboratory incidents involving HPTs. Throughout the years, the number of reported suspected and confirmed LAls has varied. In 2016, four incidents led to a suspected or confirmed LAl, and in the following year, of all six reported LAls, five were suspected and one was confirmed. In 2018, the number of confirmed LAls remained the same as that of the previous year (1-3). Unlike the mandatory reporting system used in Canada, the majority of reporting concerned with LAls in other countries, including the United Kingdom and United States, is done so voluntarily or captured through surveys (4-6).

The Public Health Agency of Canada (PHAC) Centre for Biosecurity is mandated to protect the public from the risks posed by HPTs. It oversees activities conducted under the Human Pathogens and Toxins Act (HPTA) and the Human Pathogens and Toxins Regulations (HPTR). In response to these 
requirements, the Laboratory Incident Notification Canada (LINC) surveillance system was established in December 2015. Unless otherwise exempted, facilities handling HPTs require a license to conduct their controlled activities. A single license can cover multiple containment zones, but does not cover multiple risk groups (RGs). When registering for a license, each facility self-identifies as being part of the academic, hospital, private industry/business, public health or other government sector.

Under the HPTA $(7,8)$, HPTs can be categorized into three RGs. The majority of work performed in federally regulated laboratories is with RG2 pathogens that pose a minor risk to public health, but a moderate risk to individuals. The RG3 pathogens pose a high risk to individuals, but a low risk to public health. The RG4 pathogens present the highest risk to both individuals and the community. Security-sensitive biological agents (SSBA) above a trigger quantity can pose a risk to Canada's national security. Outside the scope of the HPTA are RG1 pathogens, which are not regulated in Canada and are of lowest risk. Working with pathogens and toxins in their natural environment may also present risk with incidents involving exposures and LAls. Though the reporting of incidents involving these pathogens and toxins is not mandatory, PHAC encourages voluntary reporting, and continues to address this source of risk.

In accordance with the HPTA, licenced facilities that work with HPTs of RG2 or higher must report any laboratory incidents to PHAC without delay. The four types of laboratory incidents to be reported to LINC surveillance system are as follows:

- Exposures and LAls

- Inadvertent possession, production and/or release of an HPT

- Missing, lost, or stolen HPT, including SSBA not being received within 24 hours of expected arrival

- Changes in biocontainment

The initial report from the licence holder to PHAC following an incident provides key dates, cause of exposure, affected persons and HPTs involved. A follow-up report is expected within 15 days after the first notification for SSBA incidents, or within 30 days for other exposures or LAls. Follow-up reporting allows for identifications of trends and reduces the risk of future incidents by providing information on investigation outcomes, treatment and monitoring of affected persons, root causes and corrective actions following the incident.

The 2019 annual report marks the fourth year of the program. As with previous years, the objective of this report is to describe the distribution of laboratory incidents, focusing on data of exposures and LAls. Further, it aims to compare exposure incidents with those of previous years, describe laboratory exposures by sector, HPT, occurrence type, activity, number of people exposed (their regular role, education, years of laboratory experience and route of exposure) and root causes.

\section{Methods}

\section{Data sources}

Notification and follow-up reports of laboratory incidents are submitted through LINC's external Biosecurity Portal interface, and this information is captured by its internal Customer Relationship Management system. For this report, laboratory incidents that took place from January 1, 2019 to December 31, 2019 were extracted from the Customer Relationship Management system. Incidents that did not have a known occurrence date were also included if they were reported during this period. Data of the most recent follow-up reports were used for analysis, while the data of initial reports were used where corresponding follow-up reports and/or data were not present as of the data extraction date, February 11, 2020. Extracted data were cleaned by inspecting for and investigating any outliers and removing duplicate entries.

Within the scope of the HPTA/HPTR, an exposure incident was defined as a laboratory incident that could have resulted in intoxication/infection or had resulted in suspected or confirmed LAI $(7,8)$. A non-exposure incident referred to inadvertent possession, production or release of a pathogen or toxin, a missing, lost or stolen pathogen or toxin or a security-sensitive biological agent not being received within 24 hours of expected arrival. Incidents involving agents in the natural environment were excluded from analysis because reporting of these incidents is voluntary.

\section{Analysis}

Report data within the LINC surveillance system was extracted to Microsoft Excel 2016 for analysis and R 3.5.1 was used to perform descriptive statistics with cross-validation using SAS EG 7.1. All notified exposure incidents were first subdivided into ruled out incidents and confirmed incidents, with confirmed and suspected LAls included in the latter. Affected persons in confirmed incidents were also subdivided into confirmed or ruled out individuals. Among confirmed exposure incidents, the numbers of incidents were analyzed against parameters obtained at two levels of reporting. At the level of the active license holder, the distributions of incidents by sector, main activity, root cause, occurrence type, and implicated pathogen/toxin reported were examined. At the level of persons affected in these incidents, the distributions of their highest level of education, years of experience, route of exposure, sector and regular role were examined. A comparison of exposure incidents over time from 2016-2019, and a measure of the exposure incident rate per 100 active licenses in 2019, were also performed. Active licenses were referred to as licenses that were considered active during 2019 and were able to report an incident. The period of surveillance was one year and was defined as January 1, 2019 to December 31, 2019. The calculation for exposure incident rate $(R)$ was derived from well-established epidemiologic principles (9) and was defined as follow:

$\mathrm{R}=\frac{\text { number of exposure incidents reported during period of surveillance }}{\text { total active licenses } \times \text { period of surveillance }} \times 100$ active licenses 


\section{Results}

In 2019, there were 996 active licenses held across Canada permitting the use of HPTs. Compared with $2018(n=89)$, there were fewer confirmed exposure incidents reported $(n=60)$ but one more confirmed LAI ( $n=2)$ (Figure 1).

Figure 1: Confirmed exposure incidents, suspected and confirmed laboratory-acquired infections and active licenses, Canada, 2016-2019

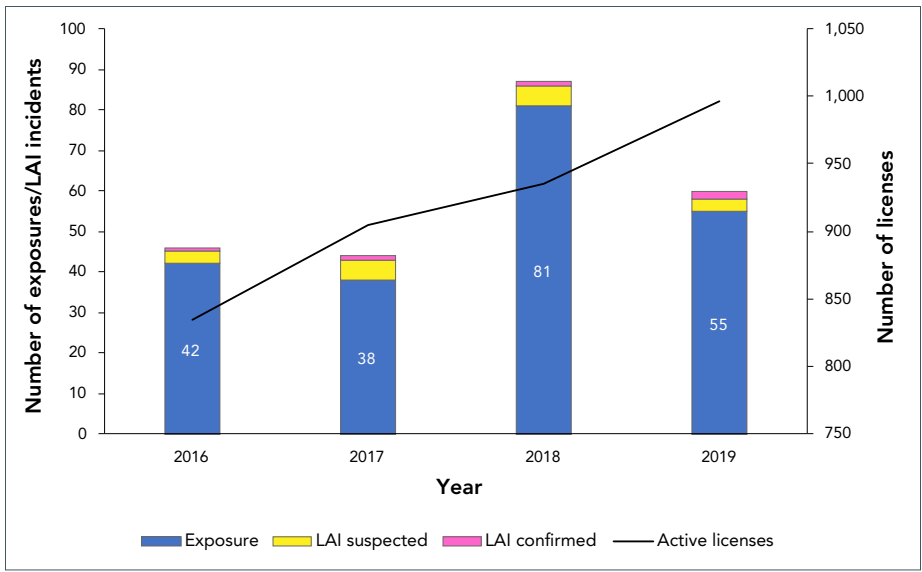

Abbreviation: LAl, laboratory-acquired infections

The exposure incident rate was approximately six incidents for every 100 active licenses observed during 2019. From January 1, 2019 to December 31, 2019, 64 exposure incidents, 199 non-exposure incidents and 19 other incidents were reported through LINC (Figure 2). Among exposure incidents, four incidents were ruled out from analysis upon further investigation, three incidents resulted in suspected LAl and two incidents resulted in confirmed LAI. In total, 99 people were reportedly exposed in laboratory incidents but 13 of these individuals were ruled out from analysis upon further investigation due to reasons such as reclassification of an exposure incident as a non-exposure incident upon review.

Figure 2: Types of incidents reported to Laboratory Incident Notification Canada and exposure incidents included in analysis, Canada 2019

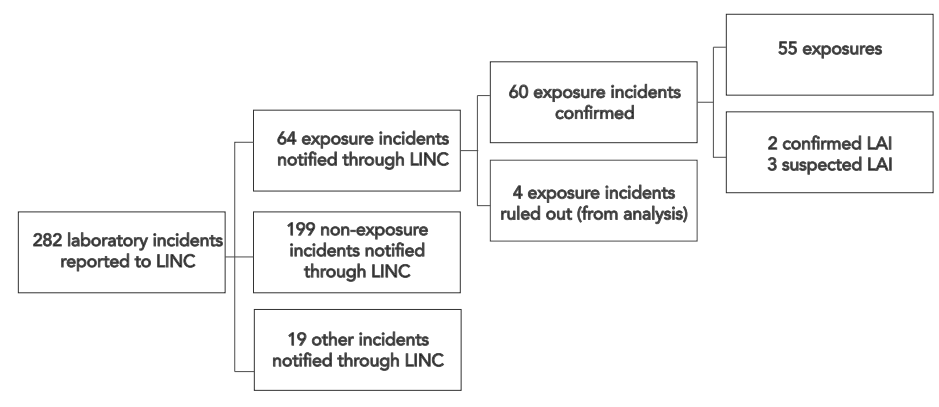

Abbreviations: LAI, laboratory-acquired infections; LINC, Laboratory Incident Notification Canada
Exposure incidents by main activity and sector

Microbiology was the main activity being performed during most exposure incidents $(n=39 ; 65.0 \%)$ followed by in vivo animal research $(n=9 ; 15.0 \%)$. Less frequently cited activities included animal care, autopsy or necropsy, cell culture, education or training, maintenance, molecular investigations, serology or hematology or other $(n=12 ; 20.0 \%)$. Definitions of the main activities can be found in Appendix A.

Figure 3 compares the number of exposure incidents reported and number of active licenses held by sector. Most exposure incidents reported through LINC occurred in the academic $(n=22 ; 36.7 \%)$, hospital $(n=18 ; 30.0 \%)$ and public health $(n=14$; $23.3 \%$ ) sectors. Furthermore, the public health sector had the greatest number of exposure incidents for every 100 licenses held (40 incidents per 100 active licenses) while the private sector had the lowest (one incident per 100 active licenses) despite having the highest number of active licenses $(n=482)$.

Figure 3: Confirmed exposures incidents and active licenses by sector reported to Laboratory Incident Notification Canada, Canada 2019

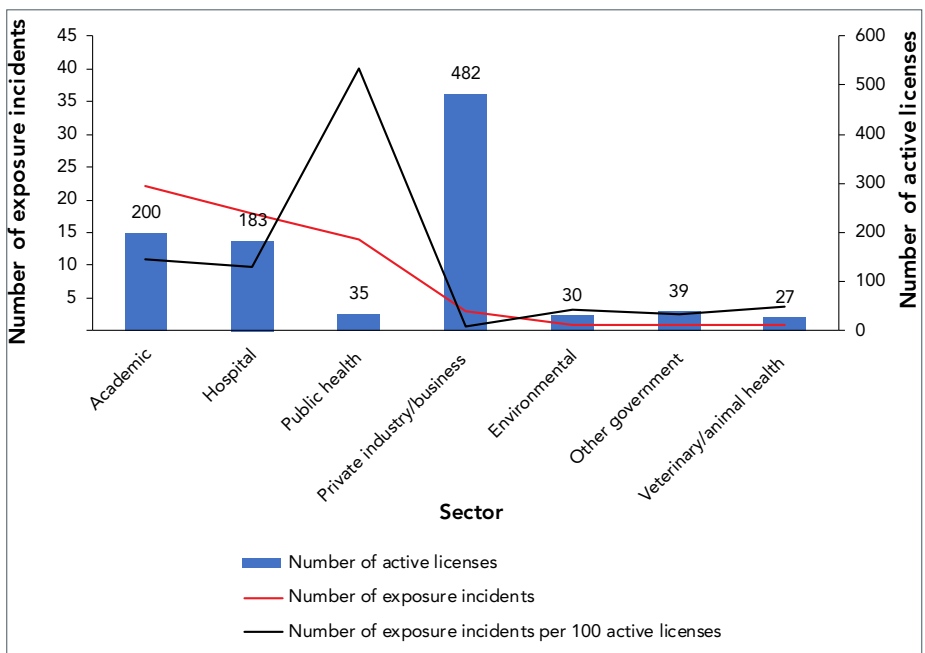

Implicated human pathogens and toxins

Salmonella was the agent implicated in both of the confirmed LAls that occurred in 2019. Table 1 shows the distribution of biological agents involved in exposure incidents reported (bacteria, fungus, parasite, virus, unknown) by security status (non-SSBA, SSBA) and risk group (RG2, RG3, unknown). Among the 71 pathogens and toxins implicated, most exposure incidents involved non-SSBA pathogens and toxins $(n=61 ; 85.9 \%)$ and/or occurred in RG2 licensed laboratories ( $n=44 ; 62.0 \%)$. Bacteria were the most implicated $(n=45 ; 63.4 \%)$ agent and parasites were the least implicated $(n=1 ; 1.4 \%)$. The most implicated agents among RG2 licensed laboratories were Neisseria meningitidis (N. meningitidis) ( $n=5 ; 7.0 \%)$, Staphylococcus aureus (S. aureus) ( $n=4 ; 5.6 \%)$, and Escherichia species $(n=3,4.2 \%)$. The most implicated agent in RG3 licensed laboratories was Brucella melitensis (B. melitensis) $(n=5 ; 7.0 \%)$. 
Table 1: Human pathogens or toxins involved in reported exposure incidents by risk group level and security sensitive status, Canada 2019 ( $N=71$ )

\begin{tabular}{|c|c|c|c|c|c|c|}
\hline \multirow{2}{*}{$\begin{array}{l}\text { Biological } \\
\text { agent } \\
\text { type by } \\
\text { risk group }\end{array}$} & \multicolumn{2}{|c|}{ Non SSBA } & \multicolumn{2}{|c|}{ SSBA } & \multicolumn{2}{|c|}{ Total } \\
\hline & $\mathbf{n}$ & $\%$ & $\mathbf{n}$ & $\%$ & $\mathbf{n}$ & $\%$ \\
\hline RG2 & 44 & 72 & 0 & 0 & 44 & 62 \\
\hline Bacteria & 32 & 52 & 0 & 0 & 32 & 45 \\
\hline Fungus & 2 & 3 & 0 & 0 & 2 & 3 \\
\hline Parasite & 1 & 2 & 0 & 0 & 1 & 1 \\
\hline Virus & 9 & 15 & 0 & 0 & 9 & 13 \\
\hline Unknown & 0 & 0 & 0 & 0 & 0 & 0 \\
\hline RG3 & 8 & 13 & 10 & 100 & 18 & 25 \\
\hline Bacteria & 4 & 7 & 9 & 90 & 13 & 18 \\
\hline Fungus & 2 & 3 & 1 & 10 & 3 & 4 \\
\hline Parasite & 0 & 0 & 0 & 0 & 0 & 0 \\
\hline Virus & 2 & 3 & 0 & 0 & 2 & 3 \\
\hline Unknown & 0 & 0 & 0 & 0 & 0 & 0 \\
\hline Unknown & 9 & 15 & 0 & 0 & 9 & 13 \\
\hline Bacteria & 0 & 0 & 0 & 0 & 0 & 0 \\
\hline Fungus & 0 & 0 & 0 & 0 & 0 & 0 \\
\hline Parasite & 0 & 0 & 0 & 0 & 0 & 0 \\
\hline Virus & 0 & 0 & 0 & 0 & 0 & 0 \\
\hline Unknown & 9 & 15 & 0 & 0 & 9 & 13 \\
\hline Total & 61 & 100 & 10 & 100 & 71 & 100 \\
\hline
\end{tabular}

Note: Percentages rounded to the nearest whole number

\section{Occurrence types}

Figure 4 presents the reported types of occurrence involved in exposure incidents. Procedural $(n=18,23.1 \%)$ and sharps-related $(n=15 ; 19.2 \%)$ were the most commonly reported types of occurrences.
Figure 4: Reported occurrence types involved in reported exposure incidents, Canada 2019 ( $N=78)$

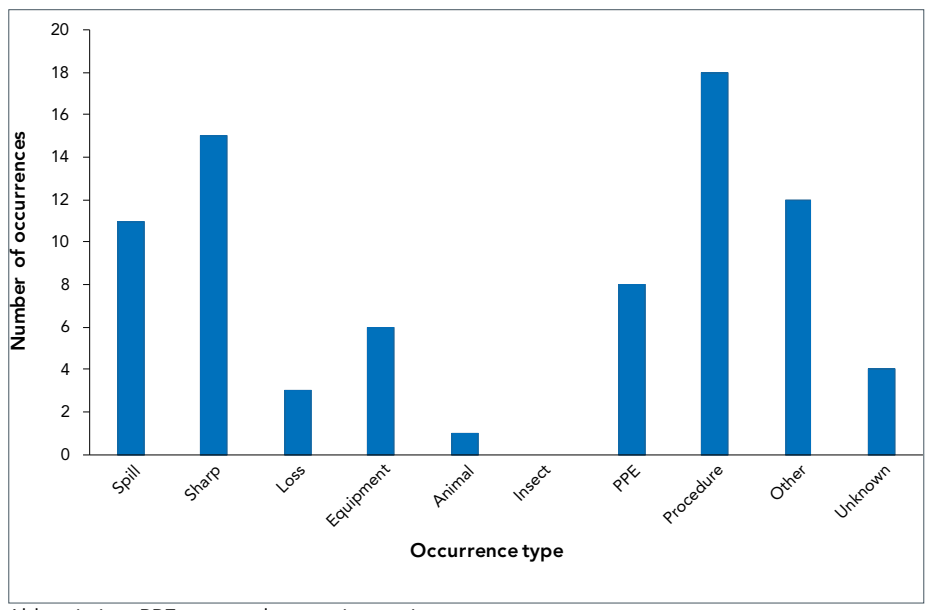

Abbreviation: PPE, personal protective equipment

\section{Exposed individuals}

In total, 86 individuals were exposed through the 60 confirmed exposure incidents reported to LINC. The highest level of education was unknown for seven exposed individuals. Most exposed individuals had a technical/trades diploma $(n=48 ; 55.8 \%)$ or Bachelor's degree $(n=15 ; 17.4 \%)$. Other highest education levels reported included high school diploma $(n=6 ; 7.0 \%)$, Master's degree $(n=7 ; 8.1 \%)$ and MD or PhD $(n=3 ; 3.5 \%)$.

Table 2 presents the number of exposed individuals by their sector and main role. A majority of individuals exposed belonged to the hospital $(n=38 ; 44.2 \%)$, public health $(n=22 ; 25.6 \%)$, or academic $(n=19 ; 22.1 \%)$ sectors. Notably, most individuals exposed were technicians or technologists $(n=64 ; 74.4 \%)$ belonging mainly to the hospital $(n=31)$ or public health $(n=21)$ sectors.

Table 2: Individuals affected in exposure incidents reported by sector and main role, Canada 2019 ( $N=86)$

\begin{tabular}{|c|c|c|c|c|c|c|c|c|c|c|c|c|c|c|}
\hline \multirow{3}{*}{ Sector } & \multicolumn{14}{|c|}{ Main role } \\
\hline & \multicolumn{2}{|c|}{$\begin{array}{l}\text { Animal } \\
\text { handler }\end{array}$} & \multicolumn{2}{|c|}{ Researcher } & \multicolumn{2}{|c|}{ Student } & \multicolumn{2}{|c|}{$\begin{array}{c}\text { Supervisor/ } \\
\text { manager }\end{array}$} & \multicolumn{2}{|c|}{$\begin{array}{l}\text { Technician/ } \\
\text { technologist }\end{array}$} & \multicolumn{2}{|c|}{ Other ${ }^{a}$} & \multicolumn{2}{|c|}{ Total } \\
\hline & $\mathbf{n}$ & $\%$ & $n$ & $\%$ & $n$ & $\%$ & $n$ & $\%$ & $n$ & $\%$ & $n$ & $\%$ & $n$ & $\%$ \\
\hline Academic & 1 & 100 & 2 & 100 & 9 & 69 & 1 & 50 & 5 & 8 & 1 & 25 & 19 & 22 \\
\hline Hospital & 0 & 0 & 0 & 0 & 4 & 31 & 0 & 0 & 31 & 48 & 3 & 75 & 38 & 44 \\
\hline $\begin{array}{l}\text { Private } \\
\text { industry/ } \\
\text { business }\end{array}$ & 0 & 0 & 0 & 0 & 0 & 0 & 0 & 0 & 5 & 8 & 0 & 0 & 5 & 6 \\
\hline Public health & 0 & 0 & 0 & 0 & 0 & 0 & 1 & 50 & 21 & 33 & 0 & 0 & 22 & 26 \\
\hline $\begin{array}{l}\text { Veterinary/ } \\
\text { animal health }\end{array}$ & 0 & 0 & 0 & 0 & 0 & 0 & 0 & 0 & 1 & 2 & 0 & 0 & 1 & 1 \\
\hline $\begin{array}{l}\text { Other } \\
\text { government }\end{array}$ & 0 & 0 & 0 & 0 & 0 & 0 & 0 & 0 & 1 & 2 & 0 & 0 & 1 & 1 \\
\hline Total & 1 & 100 & 2 & 100 & 13 & 100 & 2 & 100 & 64 & 100 & 4 & 100 & 86 & 100 \\
\hline
\end{tabular}

Other roles included instructor, microbiologist and medical laboratory assistant

Note: Percentages rounded to the nearest whole number 
Figure 5 depicts the distribution of exposed individuals by their years of laboratory experience and main role. Nineteen exposed individuals' number of years of laboratory experience was unknown. Supervisors and managers $(n=2)$ had the highest median years of experience $(\tilde{x}=17.5)$ while students $(n=13)$ had the lowest $(\tilde{x}=2)$. Overall, most exposed individuals had 0-5 years of laboratory experience $(n=32 ; 37.2 \%)$.

Figure 5: Individuals affected in exposure incidents reported by number of years of laboratory experience ${ }^{a}$ and main role ${ }^{b}$, Canada $2019(N=67)$

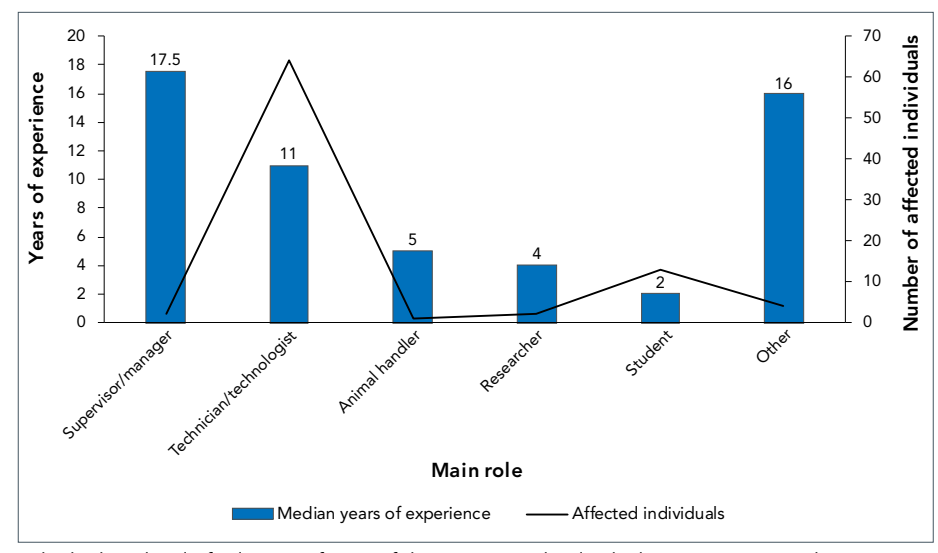

a The highest level of education for 19 of the 86 exposed individuals was not reported ${ }^{b}$ Other roles included instructor, microbiologist, and medical laboratory assistant

Among the 86 exposed individuals, most were exposed to HPTs through inhalation $(n=53 ; 61.6 \%)$ or through inoculation or injection by a needle or sharp $(n=13 ; 15.1 \%)$. Some other routes of exposure included absorption through contact with mucous membranes or skin, ingestion and inoculation or injection by a bite or scratch.

\section{Root causes and areas for laboratory safety improvement}

In total, 144 root causes were identified through follow-up reports for the 60 confirmed exposure incidents reported.

Table 3 describes the root causes and their distribution. Human interaction $(n=35 ; 24.3 \%)$ and standard operating procedures ( $n=27 ; 18.8 \%$ ) were the most commonly cited root causes, followed by management $(n=20 ; 13.9 \%)$ and equipment $(n=20 ; 13.9 \%)$.

Table 3: Root causes reported in follow-up reports of exposure incidents, Canada $2019(\mathrm{~N}=144)$

\begin{tabular}{|c|c|c|c|}
\hline \multirow{2}{*}{ Root cause } & \multirow{2}{*}{ Examples of areas of concern } & \multicolumn{2}{|c|}{ Citations } \\
\hline & & $\mathbf{n}$ & $\%$ \\
\hline \multirow[t]{2}{*}{ Communication } & $\begin{array}{l}\text { Communication did not occur but } \\
\text { should have }\end{array}$ & \multirow{2}{*}{17} & \multirow{2}{*}{12} \\
\hline & $\begin{array}{l}\text { Communication was unclear, } \\
\text { ambiguous, etc. }\end{array}$ & & \\
\hline \multirow[t]{3}{*}{ Equipment } & $\begin{array}{l}\text { Equipment quality control needed } \\
\text { improvement }\end{array}$ & \multirow{3}{*}{20} & \multirow{3}{*}{14} \\
\hline & Equipment failed & & \\
\hline & Equipment was not fit for purpose & & \\
\hline
\end{tabular}

Page 296 CCDR • September 3, $2020 \bullet$ Vol. 46 No. 9
Table 3: Root causes reported in follow-up reports of exposure incidents, Canada 2019 ( $N=144)$ (continued)

\begin{tabular}{|c|c|c|c|}
\hline \multirow{2}{*}{ Root cause } & \multirow{2}{*}{ Examples of areas of concern } & \multicolumn{2}{|c|}{ Citations } \\
\hline & & $\mathbf{n}$ & $\%$ \\
\hline \multirow[t]{2}{*}{$\begin{array}{l}\text { Human } \\
\text { interaction }\end{array}$} & $\begin{array}{l}\text { A violation (cutting a corner, not follow } \\
\text { correct procedure, deviating from } \\
\text { standard operating procedure) }\end{array}$ & \multirow{2}{*}{35} & \multirow{2}{*}{24} \\
\hline & $\begin{array}{l}\text { An error (a mistake, lapse of } \\
\text { concentration, or slip of some sort) }\end{array}$ & & \\
\hline \multirow{3}{*}{$\begin{array}{l}\text { Management } \\
\text { and oversight }\end{array}$} & Supervision needed improvement & \multirow{3}{*}{20} & \multirow{3}{*}{14} \\
\hline & $\begin{array}{l}\text { Lack of auditing of standards, policies, } \\
\text { and procedures }\end{array}$ & & \\
\hline & Risk assessment needed improvement & & \\
\hline \multirow[t]{3}{*}{ Training } & $\begin{array}{l}\text { Training not in place but should have } \\
\text { been in place }\end{array}$ & \multirow{3}{*}{17} & \multirow{3}{*}{12} \\
\hline & Training not correct for the task/activity & & \\
\hline & $\begin{array}{l}\text { Staff were not qualified or proficient in } \\
\text { performing the task }\end{array}$ & & \\
\hline \multirow{3}{*}{$\begin{array}{l}\text { Standard } \\
\text { operating } \\
\text { procedure }\end{array}$} & $\begin{array}{l}\text { Documents were followed as written } \\
\text { but not correct for activity/task }\end{array}$ & \multirow{3}{*}{27} & \multirow{3}{*}{19} \\
\hline & $\begin{array}{l}\text { Procedures not in place but should } \\
\text { have been in place }\end{array}$ & & \\
\hline & Documents were not followed correctly & & \\
\hline Other & Not applicable & 8 & 5 \\
\hline
\end{tabular}

\section{Discussion}

In 2019, 60 laboratory exposures to HPTs had been reported to LINC, a decrease from the 89 reported in 2018. Of the 60 laboratory exposures, five led to suspected LAls and two of them were confirmed. The most common agents involved in exposure incidents were RG2 and/or non-SSBA. Bacteria were the most commonly reported type of agent, with $B$. melitensis, $N$. meningitidis and $S$. aureus being the predominantly reported. The two confirmed LAls were caused by Salmonella species, which was also one of the human pathogens most frequently responsible for LAls (10-12).

The exposures occurred mostly in the public health, academic and hospital sectors and were commonly due to procedure breaches, sharps or spills and while performing microbiology activities. Eighty-six individuals, mainly technicians or technologists were exposed to a HPT. The leading root causes identified leading to an exposure were human interactions and lack of awareness or compliance with standard operating procedures.

\section{The private sector had the highest number of active licenses but the lowest rate of exposure incidents}

The distribution of exposures by sector in 2019 was similar to the previous years' and mostly occurred in the academic, hospital and public health sectors (1-3). However, the exposure incident rate (9) allowed for making an unbiased comparison across 
sectors by taking into account the number of licences per sector. Although they held the highest number of licenses, the private sector had the lowest exposure incident rate, whereas the public health sector had the highest exposure incident rate, followed by the academic and hospital sectors. These differences could be explained either by an actual difference in the exposure incident rate across sectors or by a difference in reporting exposures. A truly higher exposure incident rate in the hospital sector could be explained by a greater uncertainty in pathogens that they handle compared with the private sector, wherein most cases the pathogen is already identified (such as in vaccine development) (11). Factors influencing reporting exposure incidents across sectors in Canada are not well established and need to be explored.

The role and the experience of laboratory workers might be important factors to consider for prevention. In 2019, affected people with the lowest median years of laboratory experience were students. The academic sector is expected to be the place where students would be acquiring their first experience in the laboratory setting and represent laboratory staff at the early stages of their career. The high exposure rate in the academic sector may partially be explained by the well-established link between lack of experience and increased risk of errors (13). Another explanation could be the complexity of the organisational structure in academic settings that may perhaps lead to an unawareness of accountability from students, researchers and administrators. Such a situation could potentially result in non-compliance with safety requirements, thereby engendering exposure incidents (14).

\section{Unawareness of the occurrence of an exposure might be an underlying cause of laboratory- acquired infections}

As reported in previous reports and concurrent with literature, the most common pathogens involved in exposure incidents in 2019 were bacteria, mainly represented by B. melitensis, N. meningitidis and S. aureus. However, the two confirmed LAls were caused by Salmonella species, which is also one of the human pathogens most frequently responsible for LAls (10-12). In the case of these two LAls, no postexposure prophylaxis was given following the exposure incident because the affected persons were not aware of the exposure at the time of occurrence. The exposure was established retrospectively after onset of symptoms and suspicion of a LAI. The absence of postexposure prophylaxis could have been one of the factors that contributed to the exposure becoming a LAI (15). Unawareness of the exposure could have been the result of human interactions and lack of awareness of standard operating procedures. These factors have frequently been identified as the root causes of exposures in past years (1-3).

\section{Strengths and limitations}

The main strength of this study was the standardized and mandatory reporting process of laboratory incidents in laboratories across Canada. This provided a near real-time assessment of trends and potential for risk mitigation in prescribing or improving corrective measures at licensed facilities. Regular communication with stakeholders through Eblasts and newsletters allowed for the identification of potential risk factors. For example in 2019, the main activity involved was microbiology. This information could be used by licenced facilities to examine current safety protocols involving this activity to reduce the risk of exposures to laboratory workers in the future.

The current surveillance system of laboratory incidents does not currently capture information such as laboratory workforce size or distribution of roles within laboratories. Therefore, the main limitations of this report were the reduced accuracy inherent to using active licenses as a proxy for workforce size and the inability to report on more comprehensive trend analysis of incidents in 2019 and over time. In addition, all reportable incidents and exposures may not have been reported to LINC. We continue to address this possible issue through various compliance and monitoring activities as well as consistent communications with stakeholders through newsletters and biosafety advisories. We are also updating the notification and reporting guideline to address the process of reporting pathogens not covered by the HPTA/HPTR.

\section{Conclusion}

The annual incidence of laboratory exposures in Canada in 2019 was lower compared with 2018 but higher than in 2016 and 2017. It remains unclear if this was a true decrease as the LAl program has only been in place since 2015 and we are still establishing our baseline. Analysis of the reported exposures served to inform guidelines for ongoing improvement of biosafety and biosecurity in Canada.

\section{Authors' statement}

$\mathrm{AL}$ - Methodology, investigation, writing-original draft, review and editing RE - Conceptualization, methodology, investigation, writingoriginal draft, review and editing, supervision

NA - Methodology, investigation, writing-original draft, review and editing

CA - Writing-original draft, review and editing

$\mathrm{MH}-$ Writing-review and editing

\section{Competing interests}

There are no competing interests to declare.

\section{Acknowledgements}

We would like to thank our regulated parties for their continued support and constant vigilance regarding incident reporting and the staff at the Centre for Biosecurity for their expertise and input. 


\section{Funding}

This work was supported by the Public Health Agency of Canada as part of its core mandate.

\section{References}

1. Choucrallah D, Sarmiento L, Ettles S, Tanguay F, Heisz M, Falardeau E. Surveillance of laboratory exposures to human pathogens and toxins: Canada 2018. Can Commun Dis Rep 2019;45(9):244-51. DOI PubMed

2. Bienek A, Heisz M, Su M. Surveillance of laboratory exposures to human pathogens and toxins: Canada 2016. Can Commun Dis Rep 2017;43(11):228-35. DOI PubMed

3. Pomerleau-Normandin D, Heisz M, Tanguay F. Surveillance of laboratory exposures to human pathogens and toxins: Canada 2017. Can Commun Dis Rep 2018;44(11):297-304. DOI PubMed

4. Singh K. Laboratory-acquired infections. Clin Infect Dis 2009;49(1):142-7. DOI PubMed

5. Willemarck N, Van Vaerenbergh B, Descamps E, Brosius B, Dai Do Thi C, Leunda A, Baldo A. Laboratory- Acquired Infections in Belgium (2007-2012)_An Online Survey. Brussels (Belgium): Wetenschappelijk Instituut Volkgezondheid; 2015. https://www.researchgate.net/publication/291331348_ Laboratory-Acquired_Infections_in_Belgium_2007-2012_An_ online_survey

6. Wurtz N, Papa A, Hukic M, Di Caro A, Leparc-Goffart I, Leroy E, Landini MP, Sekeyova Z, Dumler JS, Bădescu D, Busquets N, Calistri A, Parolin C, Palù G, Christova I, Maurin M, La Scola B, Raoult D. Survey of laboratory-acquired infections around the world in biosafety level 3 and 4 laboratories. Eur J Clin Microbiol Infect Dis 2016;35(8):1247-58. DOl PubMed
7. Government of Canada. Human Pathogens and Toxins Act (HPTA). S.c. 2009, c. 24. Government of Canada; 2015 (modified 2020-04). https://lois-laws.justice.gc.ca/eng/ acts/H-5.67/FullText.html

8. Public Health Agency of Canada. Canadian Biosafety Standard Handbook. 2nd Edition. Ottawa (ON): PHAC; 2016 (modified 2018-08). https://www.canada.ca/en/public-health/ services/canadian-biosafety-standards-guidelines/ second-edition.html

9. Szklo M, Nieto J. Incidence rate based on person time. In: Epidemiology: Beyond the Basics. 2nd ed.: Mississauga, ON: Jones and Bartlett; 2007. p. 57.

10. Peng $H$, Bilal M, Iqbal HM. Improved Biosafety and Biosecurity Measures and/or Strategies to Tackle Laboratory-Acquired Infections and Related Risks. Int J Environ Res Public Health 2018;15(12):2697. DOI PubMed

11. Coelho AC, García Díez J. Biological Risks and Laboratory-Acquired Infections: A Reality That Cannot be Ignored in Health Biotechnology. Front Bioeng Biotechnol 2015;3:56. DOI PubMed

12. Siengsanan-Lamont J, Blacksell SD. A Review of Laboratory-Acquired Infections in the Asia-Pacific: Understanding Risk and the Need for Improved Biosafety for Veterinary and Zoonotic Diseases. Trop Med Infect Dis 2018;3(2):36. DOI PubMed

13. Plebani M. Exploring the iceberg of errors in laboratory medicine. Clin Chim Acta 2009;404(1):16-23. DOI PubMed

14. Huising R, Silbey SS. Surveillance and Regulation of Laboratory Practices. In: Felt U, Fouche R, Miller CA, Smith-Doerr L, editors. The Handbook of Science and Technology Studies. 4th ed. Cambridge MA: The MIT Press; 2013 P.793-822. https://mitpress.mit.edu/books/ handbook-science-and-technology-studies-fourth-edition

15. Centers for Disease Control and Prevention. Morbidity and Mortality Weekly Report (MMWR): Recommendations and Reports. 2001. Vol. 50, No RR-11, p-1-54. https://www.cdc. gov/mmwr/PDF/rr/rr5011.pdf

\section{Appendix A}

\section{Definitions of main activity}

Animal care: Activities such as attending to the daily care of animals and providing animals with treatment

Autopsy or necropsy: Post-mortem surgical examinations for purposes such as determining cause of death or to evaluate disease or injury for research or educational purposes

Cell culture: The process of growing cells under controlled conditions; it can also involve the removal of cells from an animal or plant

Education or training: Education or training of students and/or personnel on laboratory techniques and procedures

In vivo animal research: Experimentation with live, non-human animals

Maintenance: The upkeep, repair, and/or routine and general cleaning of equipment and facilities

Microbiology: Activities involving the manipulation, isolation, or analysis of microorganisms in their viable or infectious state

Molecular investigations: Activities involving the manipulation of genetic material from microorganisms or other infectious material for further analysis

Serology: Diagnostic examination and/or scientific study of immunological reactions and properties of blood serum Hematology: Scientific study of the physiology of blood 